\title{
Economic Diversification in Bahrain
}

\author{
Ashraf Nakibullah \\ Correspondence: Ashraf Nakibullah, Arab Open University - Bahrain Branch, Bahrain
}

Received: July 29, 2018

Accepted: August 23, 2018

Available online: August 28, 2018

doi:10.11114/aef.v5i5.3576

URL: https://doi.org/10.11114/aef.v5i5.3576

\begin{abstract}
Countries, such as the GCC countries, that predominantly rely for their income on oil resources face the reality that these sources of their income would not last forever. Thus, being a member of the GCC countries, Bahrain has been pursuing the policies of sustainable and diversified economic growth. This paper uses the share of nonoil real GDP to total real GDP as a measure of diversification to access the extent of diversification in Bahrain. The shares of nonoil GDP increased from 64\% in the beginning of this of this century to $80 \%$ in 2016 with an average annual growth rate of $6.2 \%$ for the period 2002-2016. This success story seems to have an inherent problem. A bivariate structural VAR model with nonoil real GDP and oil price shows that oil prices (indirectly oil sector) have positive impact on the movements of the nonoil real GDP. This means nonoil sector has been very much dependent on the oil sector and neutralizing the dependence is required for the post oil era.
\end{abstract}

JEL Classification: O14, O25, Q32

Keywords: the EDB, diversification, nonoil real GDP, oil price, impulse function

\section{Introduction}

Koren and Tenreyro (2010) suggested that one of the main objectives of forming the Gulf Cooperation Council (GCC) in 1981, consisting of six gulf countries of Bahrain, Kuwait, Oman, Qatar, Saudi Arabia and the United Arab Emirates, is to formulate policies and mechanisms that would lead to industrial development and the diversification of their products on a cooperative basis. They have pointed that this effort by the GCC countries' came from the backdrop of change of their fortunes with the huge oil price fluctuations in the nineteen seventies and early eighties. However, the thought of economic diversification came as soon as the oil and gas have been discovered and have become the sole source of their income (Niblock and Malik 2007, Seznec and Kirk, 2011). For example, as an effort to diversification Kuwait has established sovereign wealth funds (SWFs) as early as in 1953.

In fact the idea of diversification is more or less imbedded in policy making of all countries that predominately rely on oil resources for their income because of the realization that these sources of their income would not last forever and unpredictable oil price fluctuations. Diversification is seen as a way to sustain their standard of living post oil-era. The GCC countries are not an exception. Over the last five decades the GCC countries have been pursuing and implementing many diversification policies. In such effort, 'infrastructure has been built, education and health systems have been created, and broad range of manufacturing industries primarily servicing an international market have been established' (Hvidt, 2013, p.16). They have taken important economic reforms and have been providing finance and encouraging small and medium-sized businesses.

Realizing that export diversification is limited, they have targeted to improve manufacturing sectors in oil-based industries including refineries and import substitution industries, especially in food processing and manufacturing of construction materials.

However, as pointed out by Callen, Cherif, Hasanov, Heggazy, and Khandelwal (2014), that there is a problem in the incentive structure of the existing system affecting private and public sectors and the policies of choice between export promotion and import substitution industries. Because of the readily available of low-wage expatriates, wages in the private sectors have not pushed up, and as a result nationals of these countries find it more attractive to work in the public sectors with relatively higher wage and benefits. That is, these countries do not suffer from the traditional Dutch-disease long ago discovered by Corden and Neary (1982). Similarly, domestic firms rely on low-wage expatriate workers to produce consumption and investments goods to meet the demand for domestic markets rather than taking a risk to enter in the riskier export markets. Domestic firms seem to have had no other options than relying on 
expatriate workers because the GCC countries found it difficult to protect the infant industries through tariffs or quotas on imports (Hvidt, 2013).

There is another inherent problem in the growth model of these countries. Though these countries experienced of strong growth (especially in non-oil GDP growth) in the past decade with rising oil price, the average labor productivity growth, especially for non-oil sector has been week or negative (IMF 2013). Shebeb $(2007,2015)$ and Shebeb and Al-Saleh (2011) in a series of studies on labor productivity growth on Bahrain has corroborated this fact. Shebeb (2015) has found that total labor productivity growth in the construction sector in Bahrain has been negative which is due to the negative factor-labor intensities which outweighed the small positive multifactor productivity growth. This is due to the dependence of the construction industry (like many other manufacturing industries) on the abundant unskilled labor with no human capital (Shebeb 2015). In contrast to international experience, private sector activities remain concentrated in low-skilled non-oil and non-tradable sectors (Callen, et al. 2014).

All GCC countries have now diversifications and development plans or visions: Economic Vision 2030 (Bahrain), the State Vision Kuwait 2035, Vision 2020 (Oman), Qatar National Vision 2030, Long-Term Strategy, 2005-2024 (Saudi Arabia), and Vision 2021 (UAE). These visions have one thing in common is that the diversifications should be achieved with greater participation of the private sector in the economy. They all recognize the importance of diversification but do not share the same urgency because of their uneven resource bases. Kuwait, Qatar, the UAE, and Saudi Arabia (to some extent) have anything but little urgency in diversification process (Hvidt 2013). But it is different for Oman and especially for Bahrain. One way to understand this indifference is to look at their fiscal positions. The fiscal budgets of Bahrain, Oman and Saudi Arabia break even at around US $\$ 100$ per barrel, Kuwait and the UAE need between US\$70-75 per barrel, and Qatar needs only about US\$50 per barrel (IMF 2015).

Bahrain being the smallest all the GCC countries in terms size, population, and oil reserves, historically has taken more seriously than other GCC countries. Given its small and dwindling oil reserves, soaring fiscal imbalances with recent fall in oil price, and domestic situation, Bahrain sees much urgency in diversifying its economy and especially, would like to see much higher roles of the private sectors for job creation for its citizens. Being a member of the GCC countries, Bahrain has been pursuing the policies of sustainable and diversified economic growth. Success of such policies is paramount for Bahrain given its meager and dwindling oil and gas reserves. This paper empirically investigate Bahrain's journey to diversification using some measures of diversification.

The organization of the paper is as follows: Section 2 describes background of Bahrain economy. Section 3 describes the initiatives taken by the EDB. The measures, extent and the analysis are presented in section 4 . Section 5 concludes the paper.

\section{Background}

Among all the GCC countries, Bahrain in absolute terms is the smallest in size, population and oil production (their primary sources of income) as shown in panel A of table 1 below. In 2015, its real GDP was only about 4.5\% real GDP of Saudi Arabia, the largest of the GCC countries and its 2013 daily oil production was only $1.7 \%$ of Saudi Arabia $(0.42 \%$ if shared Abu Saafa Oilfield with Saudi Arabia is excluded). However, in relative terms Bahrain is quite comparable to other GCC countries as shown in panel B of table 1. For example, as we can see from panel B of table 1 that the purchasing power parity (PPP) adjusted in 2011 international dollar per capita real GDP of Bahrain was 46,195 which is quite comparable to other GCC countries except Qatar which is running away in everything from all other GCC countries. Interesting, the PPP adjusted real GDP per capita in 2014 was higher than Canada $(42,912)$, Germany $(44,262)$, the UK $(38,422)$ and but only little less than the USA $(51,895)$. Sources of Bahrain's income (revenues) related to hydrocarbon sector are also quite comparable to other GCC countries. Share of imports to total trade (around $40 \%$ ) is also comparable to other GCC countries.

Sources of income in going forward are concern for Bahrain. Oil and gas remain the main sources of their income and all economic activities (like all other GCC countries) evolve around this sector. However, as mentioned above and seen from table 1, it has small (onshore) reserve and dwindling. The pumping of its onshore oilfield peaked to 79,000 barrel per day in 1970 and since then steadily declined to 32,000 barrel per day in 2009. However, the government of Bahrain (Tatweer Petroleum) in 2009 using new technologies revived the mature Bahrain onshore oilfield and increased its pumping capacity to about 48,000 barrel per day in 2016 which is still small given its expenditure needs. The other source of oil comes from the Abu Sa'fah offshore oilfield located on the maritime border with Saudi Arabia. The production and reserves of this field is equally shared by Bahrain and Saudi Arabia. The state owned Bahrain Petroleum Company (BAPCO) is mainly in business of selling, exporting and refining gas and oil. It refines about 260,000 barrels per day and the majority of the crude supplied by the Saudi ARAMCO though pipelines. 
Table 1. Basic Statistics

\begin{tabular}{lllllll}
\hline & Bahrain & Kuwait & Oman & Qatar & $\begin{array}{l}\text { Saudi } \\
\text { Arabia }\end{array}$ & UAE \\
\hline $\begin{array}{l}\text { Panel A } \\
\begin{array}{l}\text { Population } \\
\text { (million), 2013 }\end{array}\end{array}$ & 1.219 & 3.785 & 3.291 & 1.833 & 29.196 & 8.768 \\
$\begin{array}{l}\text { Real GDP, } \\
\text { billion US\$, 2015 }\end{array}$ & 30.7 & 138.7 & 70.6 & 214.2 & 678.3 & 367.6 \\
$\begin{array}{l}\text { Crude Oil } \\
\text { (barrel per day), }\end{array}$ & 197,597 & $2,930,121$ & 941,900 & 724,000 & $11,500,000$ & $3,627,000$ \\
$\begin{array}{l}\text { 2013 } \\
\text { SWF }\end{array}$ & 10.6 & 524 & 18 & 320 & 494 & 828 \\
\hline $\begin{array}{l}\text { Panel B } \\
\text { Real GDP Per }\end{array}$ & 46,195 & 67,335 & 42,929 & 129,490 & 49,969 & 62,535 \\
$\begin{array}{l}\text { Capita, 2014 } \\
\text { Share of imports }\end{array}$ & 0.43 & 0.35 & 0.38 & 0.33 & 0.36 & 0.45 \\
$\begin{array}{l}\text { 2000-2010 } \\
\text { Hydrocarbon- } \\
\text { related revenues, }\end{array}$ & 0.77 & 0.73 & 0.84 & 0.66 & 0.86 & 0.73 \\
$\begin{array}{l}\text { 2000-2009 } \\
\text { Current expenditure } \\
\text { /total expenditure, } \\
\text { 2000-2009 }\end{array}$ & 0.76 & 0.88 & 0.72 & 0.70 & 0.80 & 0.83 \\
\hline
\end{tabular}

Note: a World Economic Outlook (WEO), 2017, real GDP in national currencies changed to US\$ using 2015 exchange rates, b national accounts of each country, c sovereign wealth funds (SWFs in billion US\$, SWF institute January 2018), d share of imports to total trade, Hasan and Nakibullah (2015), and e Espinoza and Senhadji (2011).

The non-oil sectors (led by construction, finance and manufacturing) contributed about $80 \%$ of real GDP in 2016 . Even though the oil and gas contributed only $20 \%$, it remains the main source of government income and the problem for the government. Government' budget position changes very much with the change in world oil price as shown in figure 1. It shows government had budget deficit (left scale) all years except few years in the last decade (2004-2008) when price increased unprecedentedly. It had highest surplus (about US\$ 1.1 billion) in 2008 when oil price reached its maximum in the last decade. Soaring of oil price in the last decade could be the reason for the accelerated deficit since 2008 even though oil price was historically highest during the period 2011-2014. With the steady rise of oil price in last decade, government have taken many long-term (capital) projects in order to diversify the economy and to fulfill the objectives of the Economic Vision 2030 (discussed below) that led to deficit after 20008 (OBG, 2016a). Even the highest ever oil price during 2011-2014 could not bring down the deficit which accelerated in during 2015-2016 when oil price declined sharply. Government of Bahrain provides subsidies to meat, flour, gas, electricity and water, among others. It has started to reduce many such subsidies (OBG, 2016b).

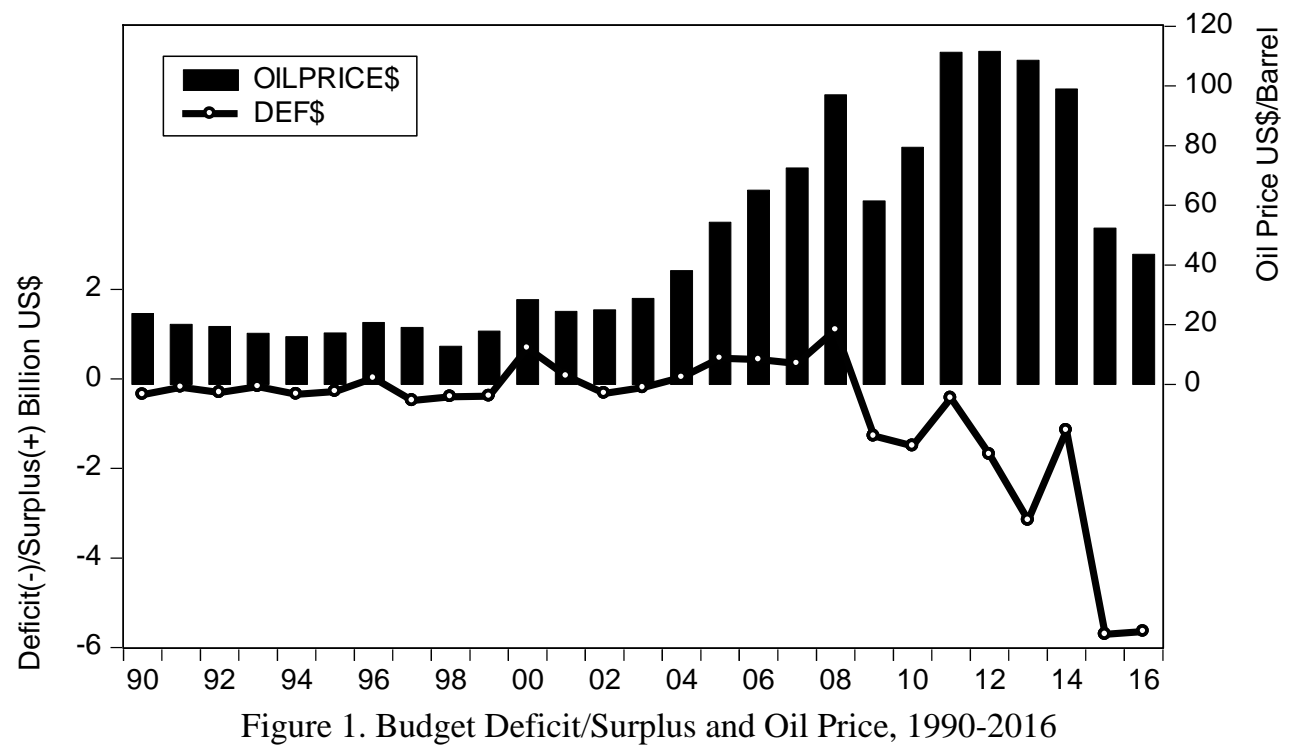


One of the reasons for budget deficit (fluctuating with oil price) is the oversized government sector which is unsustainable as per Economic Vision 2030. This is a common problem for all the GCC countries but felt more for Bahrain because of its small source of income. Private sectors of Bahrain in line with other GCC countries produce to satisfy part of the consumption and investment needs of the domestic economy but they employ very few Bahraini workers. As shown in table 2, almost all employment (92\%) was in the private sectors in 2010 (latest data available) where only $18 \%$ Bahrainis were employed. Private sectors rely mainly on low-wage (US\$550/month compared to US $\$ 1,575 /$ month for bahraini) expatriate workers and $82 \%$ workers were non-Bahraini.

Table 2. Employment (\%) and Wages (US\$) in 2010

\begin{tabular}{llll}
\hline & & Private Sector & Public Sector \\
& & 92 & 8 \\
Employment & Bahraini & 18 & 87 \\
Non-Bahraini & 82 & 13 \\
& Nonthly wage & & \\
& Bahraini & 1,575 & 2,175 \\
\hline
\end{tabular}

Source: Economic Indicators, Central Bank of Bahrain (CBB).

\section{The EDB and the Economic Vision 2030}

The Economic Development Board (EDB) of Bahrain, formed in 2000, is mandated to help both current and new prospective investors with their initiatives and enhance the investment climate in Bahrain. Among many other strategies, it has placed private sector at the center of attention with the idea that the private sector would drive the development process with entrepreneurship and innovation. For example, it contributed to the establishment of Mumtalakat Holding Company in 2006, in which a significant number of major enterprises in Bahrain were transferred including Aluminium Bahrain (Alba), Gulf Air, Bahrain Telecommunications Company (Batelco) and the National Bank of Bahrain (NBB). Formation of Tamkeen in 2006 is another achievement. Tamkeen is the national labor fund focused on private sector development and its activities include improving the working skills of Bahraini workers through training programs, creation of new enterprises, and supporting the existing ones. In this regard the role of Bahrain Development Bank (BDB) established in 1992 must also be emphasized. The BDB working along with Tamkeen has been playing an important role in the growth of small and medium-sized enterprises which are essential for economic diversification (OBG, 2016a). Some inefficient government sectors (such as garbage disposal and bus transportation) have also been privatized (Ghani and Nakibullah, 2005).

Economic Vision 2030 for Bahrain (prepared by the EDB and launched in 2008) outlines the long-term development plan for Bahrain. The plan is to "shift from an economy built on oil wealth to a productive, globally competitive economy, shaped by the government and driven by a pioneering private sector - an economy that raises a broad middle class of Bahrainis who enjoy good living standards through increased productivity and high-wage jobs" (Economic Vision 2030, p. 3). In its inception in 2008, it has recognized that approximately 4000 Bahrainis (with at least a college degree) per year were entering in the labor market whereas private sectors could absorb only about 1,100 per year that would put huge pressure on already over-sized (unsustainable) public sector. On top of that economy had shortage of both appropriate skills and quality employment which reflected in the private sectors' unwillingness to employ Bahrainis. Thus, the economy needed a much transformation that would create enough new jobs both qualitatively and quantitatively in private sectors and by attracting foreign direct investments (FDI) in the country. Creating qualitatively better skilled Bahraini workforce (as vindicated by Tamkeen) would make private sectors to prefer Bahrainis as their choice of employment.

It addresses how globalization and increased competition have been impacting Bahrain private sectors. To compete globally Bahrain private sectors have been relying mainly on low-waged expatriate workers, however, this competitive advantage has been slowing eroding as the global manufacturing units have also been shifting to those low-cost countries. As a result, it asserts "innovation and productivity have become critical sources of competitive advantage. Bahrain has to step up its performance in the following two areas: Countries worldwide have on average raised their labour productivity by 21 percent over the past 25 years, while Bahrain's improvement has been just 17 percent. On a global scale, Bahrain's innovation output is currently negligible" (Economic Vision 2030, p. 9). Thus, the vision recognizes that the importance of increased productivity and innovation by Bahrain private sectors. By attaining increased level of sophistication and innovation, the private sectors would be able to reach an attractive position in the global value chain.

It emphasizes the roles of the government, society, and especially on the private sectors empowering them to drive economic growth by increasing productivity and skills. It would create number of new medium-to high-wage jobs for Bahrainis. Bahrain diversifies the economy by strengthening the non-oil sectors. Government would create economic 
opportunities by encouraging investment beyond financial sector in diversifying non-oil sectors such as manufacturing and logistics, business services, and tourism. All these efforts would lead to the ultimate goal of the plan is that every Bahraini family would double its disposable income in real terms by 2030 (Economic Vision 2030).

\section{State of Diversification}

\subsection{Definition and Measures of Diversification}

Diversification, for the GCC countries including Bahrain, in a broader sense means to reduce their dependence from their main source of income (oil and gas) to multiple sources of income. More specifically, as the United Nations (ESCWA) regional report has described diversification for the GCC countries as: "within the context of the GCC countries, economic diversification means reducing heavy dependence of the oil sector by developing a non-oil economy, non-oil exports and non-oil revenue resources. By implication, it also means reducing the leading role of the public sector in the GCC economies by promoting the growth rate of the private sector" (ESCWA 2001, p. vii).

Based on this definition different measures of diversification can be used such as the percentage of oil versus non-oil sectors to GDP, the percentage contribution of oil revenues to total government revenue, percentage contribution of non-oil export to total

export earnings, the relative contribution of the public and the private sector to GDP, and volatility of GDP and its relation to oil price instability (Hvidt, 2013).

\subsection{Extent of Diversification}

Using the available data for Bahrain, I look at the first two measures of diversification for Bahrain, namely, share of real non-oil GDP to total to real GDP for the period 1990 to 2016, and share of oil and gas revenue to total revenue for the period 1998 to 2016. It shows that shares of non-oil GDP were steady around 68\% during 1990s and from 2000 (coincided with the formation of EDB) onward shares had increased and reached about $80 \%$ of the real GDP. However, this steady increase in non-oil sectors (may consider a success story of diversification according to this measure) has not relieved government budget woes. Figure 2 shows that the oil and gas sector contributed about $46 \%$ of total revenue in 1998 when non-oil revenues contributed the majority (54\%) of the revenue. Over the years this has changed dramatically as the share jumped to $73 \%$ in 2000 . Oil and gas sector contributed almost all (about $88 \%$ ) revenue for the last several years. This trend seems contrary to the diversification drive as one expected to see the less dependence on oil revenue. However, one may also look at it differently. The government in its drive to diversification to attract more private initiatives and FDI, kept low set up and running cost; moreover, there is no personal and corporate taxes. Figure 3 shows the recent trend of major non-oil sectors leading by construction and personal services (medical services), financial sector and manufacturing. Comparing figure 3 with figure 2, it is very clear these three sectors are the driving force for dramatic increase in the share of the non-oil sector.

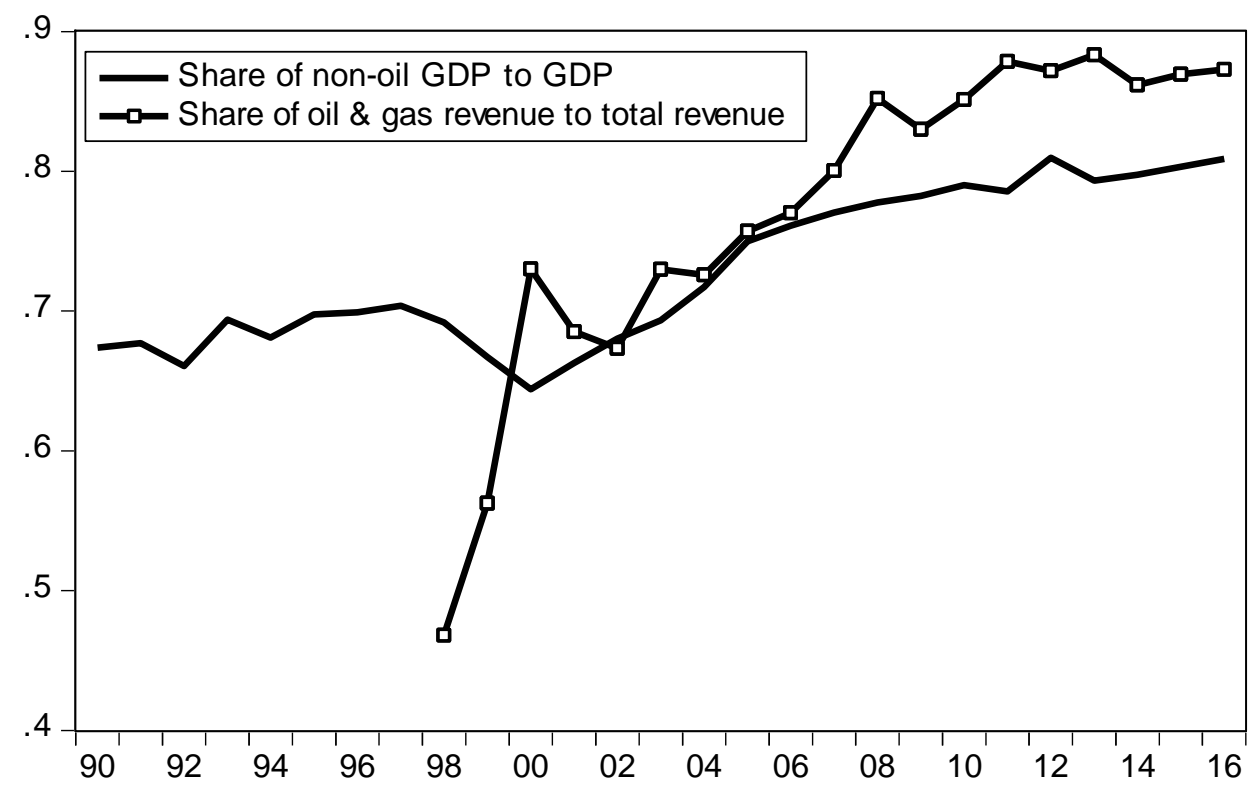

Figure 2. Percentages of non-oil GDP to GDP (1990-2016) and Oil and Gas

Revenue to Total Revenue (1998-2016) 
Data sources: Economic indicators (CBB) and World Economic Outlook (WEO) database

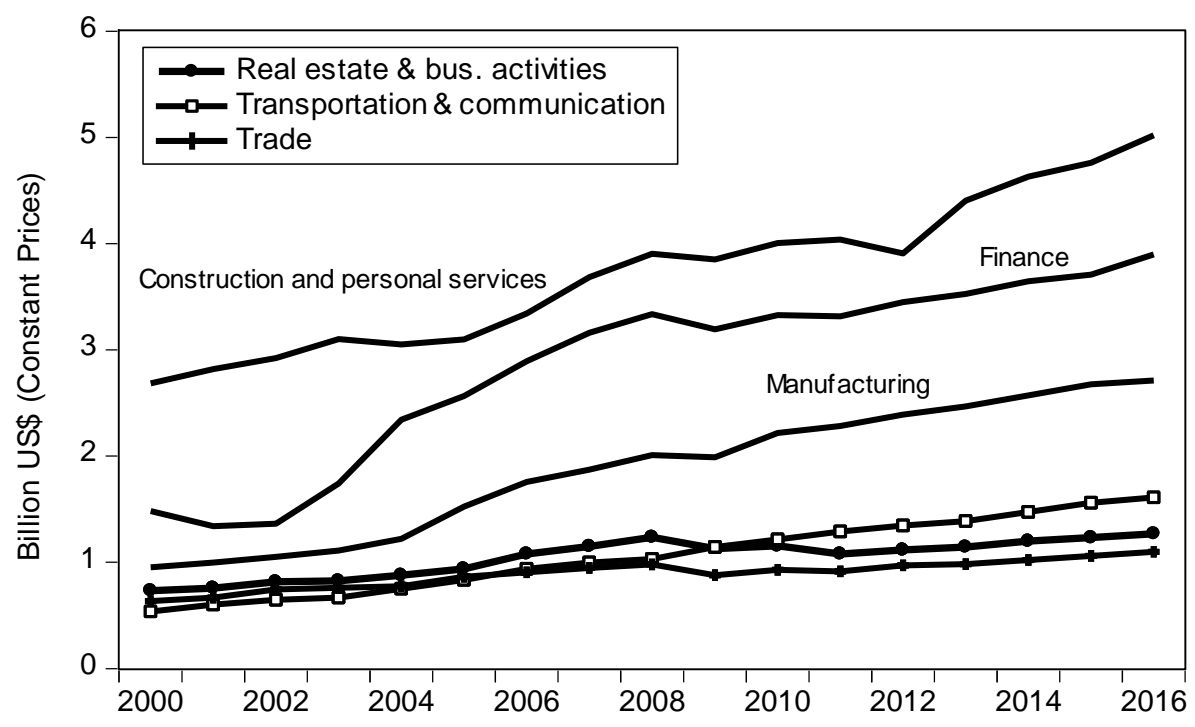

Figure 3. Trends of major non-oil sectors, 2000-2016.

\section{Empirical Evidence}

We have seen that the shares of nonoil real GDP to total GDP have been increasing over time and reached to $80 \%$ in the last few years which could be seen as success story of diversification effort by Bahrain (figure 2). The nonoil GDP grew more than $6 \%$ on average during 2000-2016. Though the oil sector is shrinking, it (especially price of oil) still believed to exert significant influence on the other sectors including nonoil sectors. The correlations between nonoil GDP and oil price were significant in levels (0.78) and in first difference (0.38) over the period 2000-2016. Obviously, purpose of diversification is to reduce exposure to overall economy due to volatile and uncertain oil price.

It is relevant to ask whether nonoil sector has been able to isolate itself through diversification from the vagaries oil price. Theoretically, it is expected the nominal oil price shocks would cause only temporary movements in nonoil GDP not permanent movements. Only the real shocks would cause permanent movements in the nonoil GDP. To test this we use bivariate structural vector autoregression (SVAR) model with nonoil real GDP and oil price to recover nominal and real shocks. We follow the Blanchard-Quah (1989) decomposition. Natural logarithms of oil price and nonoil real GDP are denoted as $p o_{t}=\ln$ (oil price) and nonoil real GDP as $n y_{t}=\ln$ (nonoil real GDP). Both $p o_{t}$ and $n y_{t}$ are nonstationary but they are first difference stationary $I(1)$. Using the first difference of each variable, the bivariate moving average representation of the $\left\{p o_{t}\right\}$ and $\left\{n y_{t}\right\}$ sequences will have the form:

$$
\left|\begin{array}{c}
\Delta p o_{t} \\
\Delta n y_{t}
\end{array}\right|=\left|\begin{array}{ll}
A_{11}(L) & A_{12}(L) \\
A_{21}(L) & A_{22}(L)
\end{array}\right|\left|\begin{array}{c}
\varepsilon_{p o t} \\
\varepsilon_{n y t}
\end{array}\right|
$$

where $\varepsilon_{\text {pot }}$ and $\varepsilon_{n y t}$ represent the zero-mean mutually uncorrelated oil price and nonoil real GDP shocks, respectively and $A_{i j}(L)$ are polynomials in the lag operator $L$. The individual coefficients of $A_{i j}(L)$ are denoted by $a_{i j}(k)$. We impose the restriction (as expected) that nonoil real GDP shocks have no long-run effect on the oil price. This implies that the sum of the coefficients in $A_{12}(L)$ sum to zero, that is,

$$
\sum_{k=0}^{\infty} a_{12}(k) \varepsilon_{2 t-k}=0
$$

This restriction along with the restriction that structural shocks are orthogonal are enough to recover structural shocks from the regression residuals of the estimated reduced form bivariate vector autoregression (VAR) consisting of $\Delta p o_{t}$ and $\Delta n y_{t}$. This exercise allows us to identify or recover the structural shocks $\varepsilon_{p o t}$ and $\varepsilon_{n y t}$ which are then used to obtain impulse response and variance decompositions as reported below.

The responses shown in figure 4 are accumulated responses of log level of nonoil real GDP to oil price and real (nonoil real GDP) shocks. A change in nonoil real GDP by .01 means $1 \%$ change in the level of nonoil real GDP in response to a one standard deviation in either oil price or real shock. Figure 4 shows nonoil real GDP rise instantly and permanently. It also shows oil price shock exerts higher impact on oil real GDP compared to its own shock. In response oil price 
shock nonoil real GDP rises by about $4.5 \%$ in the long-run whereas its own shock increases output by about $4 \%$ in the long run. These results imply that even though diversification effort resulted in more non-oil GDP private sectors in the country, their activities still impacted by the changes in oil price.

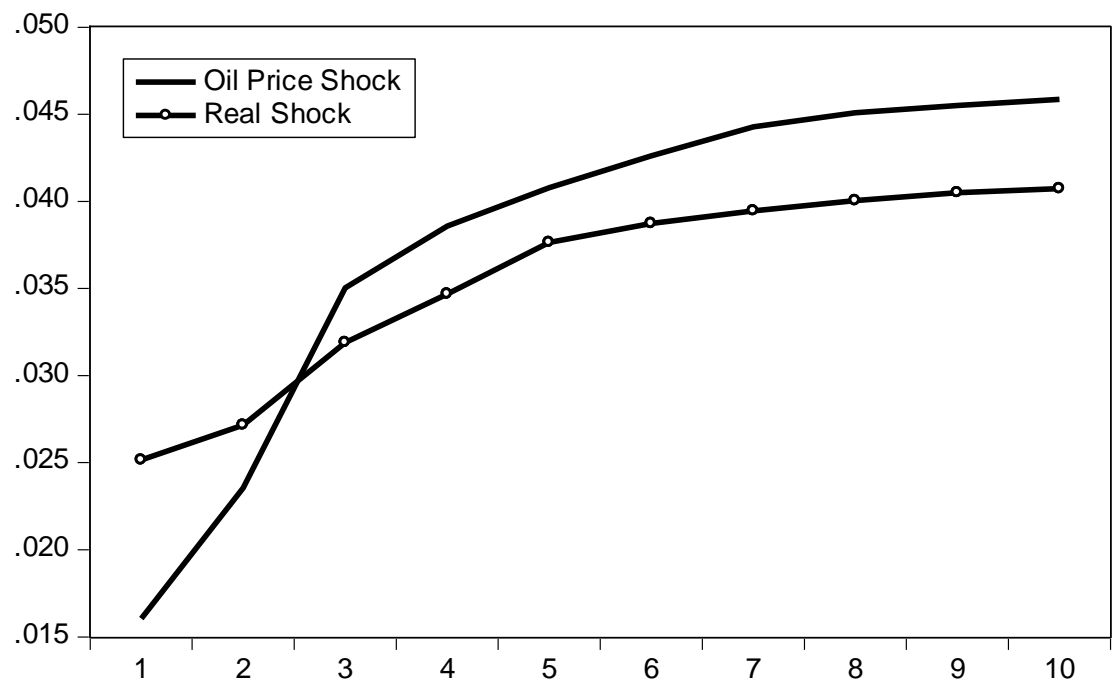

Figure 4. Cumulative response of non-oil GDP to oil price and real shocks

Table 3 shows the structural variance decomposition of the percentage change in nonoil

real GDP at time intervals (forecasting horizons) 1-2 and at time intervals 4 and 6. Oil price shocks explain about one third or more forecast error variance of the nonoil real GDP from year 2 and beyond. We may conclude that though real shocks are responsible for the majority of the movements of nonoil GDP, oil price shocks also have substantial impact.

Table 3. Variance decomposition of percentage change in nonoil real GDP

\section{Conclusion}

\begin{tabular}{lll}
\hline Horizon (year) & Oil price shock & Real shock \\
\hline 1 & 28.90 & 71.10 \\
2 & 32.99 & 67.01 \\
4 & 40.70 & 59.30 \\
6 & 40.77 & 59.23 \\
\hline
\end{tabular}

Given its limited natural resources (oil and gas), diversification is not a luxury (which may be somewhat true for some rich GCC countries) but a necessity for Bahrain. Though diversification has been imbedded in the policy of the government for a long time, it got momentum with the formation of the EDB in 2000. It has taken many initiatives in diversifying and privatizing the economy. The EDB has prepared and launched the Economic Vision 2030 in 2008 which is an ambitious long-term plan of diversifying Bahrain with less and less reliance on its dwindling oil and gas sector. Its vision is to see each Bahrain household doubles its real disposable income by 2030 .

Due to data limitation this paper uses one of the main measures of diversification (namely, share of nonoil real GDP to total real GDP) to access the extent of diversification in Bahrain. The shares of nonoil GDP increased from 64\% in 2000 to $80 \%$ in 2016 with an average annual growth rate of $6.2 \%$ for the period 2000-2016. Three major sectors construction and medical services, financial sector and manufacturing have been contributing majority of the shares and growth rates. This is definitely satisfactory achievement.

However, a closer analysis reveals an inherent problem with the diversification model. The paper uses a bivariate structural VAR model with nonoil real GDP and oil price to generate impulse responses. It shows that oil prices (indirectly oil sector) have positive impact on the movements of the nonoil real GDP. This means nonoil sector is not isolated from the oil sector what is required for the post oil era.

\section{References}

Callen, T., Cherif, R., Hasanov, F., Heggazy, A., \& Khandelwal, P. (2014). Economic Diversification in the GCC: Past, Present, and Future, IMF Staff Discussion Note, SDN/14/12, Wasgington, DC.

Corden, W. M., \& Neary, J. P. (1982). Booming Sector and De-Industrialization in a small Open Economy, The Economic Journal, 92(368), 825-848. https://doi.org/10.2307/2232670

Economic Vision 2030, https://www.evisa.gov.bh/Vision2030Englishlowresolution.pdf 
ESCWA, Economic and Social Commission for Western Asia (2001). Economic Diversification in the Oil-Producing Countries: The case of the Gulf Cooperation Council Economies. New York: United Nations.

Espinoza, R., \& Senhadji, A. (2011). How Strong are Fiscal Multipliers in the GCC? An Empirical Investigation. IMF Working Paper WP/11/61, Washington, DC.

Ghani, A. A., \& Nakibullah, A. (2005). Privatization in Bahrain, The Global Journal of Finance and Economics, 2(1), 69-86.

Hasan, M., \& Nakibullah, A. (2015). Price Level and Inflation in the GCC Countries, International Review of Economics and Finance, 39, 239-252. https://doi.org/10.1016/j.iref.2015.04.008

Hvidt, M. (2013). Economic Diversification in GCC countries: Past record and future trends, Kuwait Programme on Development, Governance and Globalisation in the Gulf States, Research paper No. 9, London School of Economics.

IMF, International Monetary Fund (2015), Regional Economic Outlook: Middle East and Central Asia, October, Washington, DC.

Koren, M., \& Tenrero, S. (2010), Volatility, Diversification and Development in the Gulf Cooperation Council Countries, Kuwait Programme on Development, Governance and Globalisation in the Gulf States, Research paper No. 9, London School of Economics.

Niblock, T., \& Malik, M. (2007). The Political Economy of Saudi Arabia, Routledge: London.

OBG, Oxford Business Group (2016a), Bahrain Economy: Diversification key to Bahrain's Holistic Economic Development, https://oxfordbusinessgroup.com

OBG, Oxford Business Group (2016b), Bahrain Economy: Subsidy cuts a tricky task for Bahrain's government, https://oxfordbusinessgroup.com

Seznec, J. F., \& Kirk, M. (eds.) (2011). Industrialization in the Gulf: A Socioeconomic Revolution, Center for Contemporary Arab Studies, Georgetown University/Routledge.

Shebeb, B. (2007), Productive Efficiency in Bahrain Economy, Middle East Journal of Economics and Finance, 1(1), $1-14$.

Shebeb, B. (2015), Analytical Decomposition of Labor Productivity Growth in Construction Industry of Bahrain, Journal of Socialomics, 5(1), 1-5. https://doi.org/10.4172/2167-0358.1000137

Shebeb, B., \& Al-Saleh, N. (2011), Economic Growth in Bahrain: The Contribution of Multifactor Productivity, International Journal of Economic Issues, 4(2), 2011.

\section{Copyrights}

Copyright for this article is retained by the author(s), with first publication rights granted to the journal.

This is an open-access article distributed under the terms and conditions of the Creative Commons Attribution license which permits unrestricted use, distribution, and reproduction in any medium, provided the original work is properly cited. 